\title{
New Trends in Corrosion Analysis of Al-Sn Alloy Duplex System
}

\author{
Chinedu Ekuma, Eziaku Osarolube, Ephraim O. Chukwuocha, Michael C. Onyeaju
}

Department of Physics, University of Port Harcourt, Port Harcourt, Nigeria.

Email: panaceamee@yahoo.com

Received February $15^{\text {th }}, 2011$; revised March $18^{\text {th }}$, 2011; accepted March $20^{\text {th }}, 2011$.

\begin{abstract}
The corrosion characterization of binary Al-Sn alloy systems has been statistically analyzed in the light of developed model equations. It was observed that the modeled corrosion penetration rate values generated using the developed model equations are in tandem with the experimental values.
\end{abstract}

Keywords: Al-Sn, Statistical Analysis, Corrosion, Model Equations, Correlation

\section{Introduction}

It has since been a worldwide problem for man to combat the menace of material degradation. Many structural failures and general loss of valuable engineering materials have been traced to be caused basically by analysis and not synthesis [1] as over 313 failure cases studied [2] have shown that well over $56.90 \%$ are due to corrosion. The causes of materials degradation with the associated environmental variables have been well explained in many literatures [3-14].

A critical look at all forms of corrosion show that they are merely a statistical phenomenon hence, the yardstick behind the adoption of statistics techniques in this present study. However, even with the somewhat semi-empirical nature of corrosion (as it show the relations between available data and measurements that do not necessarily reveal any relation between cause and effect), statistical models attempt to determine the fundamental relationship between sets of input data (predictors) and targets (predictands) $[15,16]$.

The adoption of statistical analysis in corrosion analysis in metals has been predicted for years but, its usage has been hampered primarily by the specialty skill needed in applying this principle which, its impediment lies basically on the lack of reference frame for its application [16].

In this present study, we will apply the non-linear regression analysis technique to obtain model equations that will be used to determine the corrosion parameter of interest and other statistical parameters adequate for discussing and understanding the phenomenon of corrosion (in this case, Al-Sn alloys of compositions 2.5\% and 4.5\% by weight respectively of $\mathrm{Sn}$ ) in selected media environments: $\mathrm{HCl}$ and $\mathrm{NaCl}$ of concentrations $0.5 \mathrm{M}$ and $1.0 \mathrm{M}$ respectively, using the statistical software SPSS ${ }^{\mathrm{TM}}$.

The data of Idenyi et al. [17] has been used for this analysis.

\section{Results}

The results of the corrosion penetration rate values for the experimental and modeled values are as shown in Tables 1 to 8, while Table 9 is the model equation of the corrosion parameters of the various Al-Sn alloy systems in the various concentrations of hydrochloric acid and brine environments.

\section{Discussion of Results}

A cursory look at Tables 1-8 clearly reveals that the modeled corrosion penetration values of the various binary alloy samples subjected to the varying concentrations $(0.5 \mathrm{M}$ and $1.0 \mathrm{M}$ ) of hydrochloric acid and brine environments respectively, are in tandem with the observed experimental values. This is further confirmed by the nearly perfect coefficient of correlations of all the composites which is in the range $0.94 \leq R \leq 1.00$ (see Table 9). The implication of this high positive coefficient of correlation is that the modeled values are in good agreement with the experimental data. Thus, our model can be of good usage in studying effect of the studied environments on Al-Sn binary alloy system on expanded time scale. In order to further confirm the dependence of the corrosion penetration rate mainly on the exposure 
Table 1. CPR Data for $\mathrm{Al}-2.5 \% \mathrm{Sn}$ in $0.5 \mathrm{M} \mathrm{HCl}$ Environment.

\begin{tabular}{ccc}
\hline Time (Hrs) & $\begin{array}{c}\text { Experimental CPR } \\
(\mathrm{mm} / \mathrm{yr})\end{array}$ & $\begin{array}{c}\text { Modeled CPR } \\
(\mathrm{mm} / \mathrm{yr})\end{array}$ \\
\hline 12 & 2.08 & 1.763 \\
24 & 1.25 & 1.334 \\
36 & 0.90 & 1.083 \\
48 & 0.73 & 0.905 \\
60 & 0.62 & 0.767 \\
72 & 0.55 & 0.654 \\
84 & 0.51 & 0.559 \\
96 & 0.47 & 0.477 \\
108 & 0.44 & 0.404 \\
120 & 0.43 & 0.338 \\
132 & 0.42 & 0.28 \\
144 & 0.39 & 0.226 \\
\hline
\end{tabular}

Table 2. CPR Data for $\mathrm{Al}-2.5 \% \mathrm{Sn}$ in $1.0 \mathrm{M} \mathrm{HCl}$ Environment.

\begin{tabular}{ccc}
\hline Time (Hrs) & $\begin{array}{c}\text { Experimental CPR } \\
(\mathrm{mm} / \mathrm{yr})\end{array}$ & $\begin{array}{c}\text { Modeled CPR } \\
(\mathrm{mm} / \mathrm{yr})\end{array}$ \\
\hline 12 & 3.12 & 2.815 \\
24 & 2.08 & 2.201 \\
36 & 1.66 & 1.843 \\
48 & 1.46 & 1.588 \\
60 & 1.25 & 1.391 \\
72 & 1.14 & 1.229 \\
84 & 1.07 & 1.093 \\
96 & 1.01 & 0.975 \\
108 & 0.92 & 0.870 \\
120 & 0.85 & 0.777 \\
132 & 0.79 & 0.693 \\
144 & 0.74 & 0.616 \\
\hline
\end{tabular}

Table 3. CPR Data for $\mathrm{Al}-2.5 \% \mathrm{Sn}$ in $0.5 \mathrm{M}$ NaCl Environment.

\begin{tabular}{ccc}
\hline Time (Hrs) & $\begin{array}{c}\text { Experimental CPR } \\
(\mathrm{mm} / \mathrm{yr})\end{array}$ & $\begin{array}{c}\text { Modeled CPR } \\
(\mathrm{mm} / \mathrm{yr})\end{array}$ \\
\hline 12 & 3.74 & 3.201 \\
24 & 2.29 & 2.488 \\
36 & 1.66 & 2.071 \\
48 & 1.46 & 1.775 \\
60 & 1.37 & 1.545 \\
72 & 1.35 & 1.358 \\
84 & 1.22 & 1.199 \\
96 & 1.12 & 1.062 \\
108 & 1.02 & 0.941 \\
120 & 0.94 & 0.832 \\
132 & 0.87 & 0.734 \\
144 & 0.81 & 0.645 \\
\hline
\end{tabular}

time (though alloy composition and other physical factors play a vital role in corrosion experiments), the coefficient of determination of the various samples in their different environments were also determined. It can be verified (see Table 9) that the range of the coefficients of determination is $0.88 \leq R^{2} \leq 0.99$. This shows that approximately $92.64 \%$ of the total variation in the corrosion
Table 4. CPR Data for Al - 2.5\% Sn in 1.0 M NaCl Environment.

\begin{tabular}{ccc}
\hline Time (Hrs) & $\begin{array}{c}\text { Experimental CPR } \\
(\mathrm{mm} / \mathrm{yr})\end{array}$ & $\begin{array}{c}\text { Modeled CPR } \\
(\mathrm{mm} / \mathrm{yr})\end{array}$ \\
\hline 12 & 2.50 & 2.140 \\
24 & 1.46 & 1.646 \\
36 & 1.18 & 1.357 \\
48 & 0.99 & 1.152 \\
60 & 0.87 & 0.993 \\
72 & 0.80 & 0.863 \\
84 & 0.71 & 0.753 \\
96 & 0.65 & 0.657 \\
108 & 0.62 & 0.573 \\
120 & 0.58 & 0.498 \\
132 & 0.55 & 0.430 \\
144 & 0.52 & 0.368 \\
\hline
\end{tabular}

Table 5. CPR Data for $\mathrm{Al}-4.5 \% \mathrm{Sn}$ in $0.5 \mathrm{M}$ HCl Environment.

\begin{tabular}{ccc}
\hline Time (Hrs) & $\begin{array}{c}\text { Experimental CPR } \\
(\mathrm{mm} / \mathrm{yr})\end{array}$ & $\begin{array}{c}\text { Modeled CPR } \\
(\mathrm{mm} / \mathrm{yr})\end{array}$ \\
\hline 12 & 3.12 & 2.549 \\
24 & 1.66 & 1.890 \\
36 & 1.18 & 1.505 \\
48 & 0.94 & 1.231 \\
60 & 0.79 & 1.019 \\
72 & 0.73 & 0.846 \\
84 & 0.64 & 0.699 \\
96 & 0.60 & 0.573 \\
108 & 0.54 & 0.461 \\
120 & 0.5 & 0.360 \\
132 & 0.46 & 0.270 \\
144 & 0.43 & 0.187 \\
\hline
\end{tabular}

Table 6. CPR Data for $\mathrm{Al}-4.5 \% \mathrm{Sn}$ in $1.0 \mathrm{M} \mathrm{HCl}$ Environment.

\begin{tabular}{ccc}
\hline Time (Hrs) & $\begin{array}{c}\text { Experimental CPR } \\
(\mathrm{mm} / \mathrm{yr})\end{array}$ & $\begin{array}{c}\text { Modeled CPR } \\
(\mathrm{mm} / \mathrm{yr})\end{array}$ \\
\hline 12 & 3.33 & 2.724 \\
24 & 1.77 & 2.012 \\
36 & 1.25 & 1.596 \\
48 & 0.99 & 1.30 \\
60 & 0.85 & 1.071 \\
72 & 0.75 & 0.884 \\
84 & 0.65 & 0.725 \\
96 & 0.6 & 0.588 \\
108 & 0.55 & 0.467 \\
120 & 0.51 & 0.359 \\
132 & 0.47 & 0.261 \\
144 & 0.44 & 0.172 \\
\hline
\end{tabular}

penetration rate in the whole environments is accounted for by the corresponding variation in the exposure time.

The remaining $7.36 \%$ may be due to alloy composition and other factors not incorporated in the model equations. This is overwhelmingly significant and it further confirms that the developed model equations will be a good 
Table 7. CPR Data for $\mathrm{Al}-4.5 \% \mathrm{Sn}$ in $0.5 \mathrm{M} \mathrm{NaCl}$ Environment.

\begin{tabular}{ccc}
\hline Time (Hrs) & $\begin{array}{c}\text { Experimental CPR } \\
(\mathrm{mm} / \mathrm{yr})\end{array}$ & $\begin{array}{c}\text { Modeled CPR } \\
(\mathrm{mm} / \mathrm{yr})\end{array}$ \\
\hline 12 & 3.95 & 3.941 \\
24 & 3.02 & 3.074 \\
36 & 2.77 & 2.568 \\
48 & 2.18 & 2.208 \\
60 & 1.87 & 1.929 \\
72 & 1.63 & 1.702 \\
84 & 1.43 & 1.509 \\
96 & 1.27 & 1.342 \\
108 & 1.16 & 1.195 \\
120 & 1.08 & 1.063 \\
132 & 1.00 & 0.944 \\
144 & 0.95 & 0.835 \\
\hline
\end{tabular}

Table 8. CPR Data for $\mathrm{Al}-4.5 \% \mathrm{Sn}$ in $0.5 \mathrm{M} \mathrm{NaCl}$ Environment.

\begin{tabular}{ccc}
\hline Time (Hrs) & $\begin{array}{c}\text { Experimental CPR } \\
(\mathrm{mm} / \mathrm{yr})\end{array}$ & $\begin{array}{c}\text { Modeled CPR } \\
(\mathrm{mm} / \mathrm{yr})\end{array}$ \\
\hline 12 & 3.53 & 3.483 \\
24 & 2.91 & 2.656 \\
36 & 2.15 & 2.173 \\
48 & 1.66 & 1.83 \\
60 & 1.37 & 1.564 \\
72 & 1.18 & 1.346 \\
84 & 1.04 & 1.162 \\
96 & 0.94 & 1.003 \\
108 & 0.86 & 0.863 \\
120 & 0.79 & 0.737 \\
132 & 0.78 & 0.623 \\
144 & 0.75 & 0.520 \\
\hline
\end{tabular}

Table 9. The Modeled Corrosion Parameters for the Various Al-Sn Alloys in Different Media Concentration.

\begin{tabular}{|c|c|c|c|}
\hline $\begin{array}{l}\text { MEDIA CONCEN- } \\
\text { TRATION }\end{array}$ & $\begin{array}{l}\text { COEFFICIENT OF CORRELA- } \\
\text { TION (R - VALUES) }\end{array}$ & $\begin{array}{l}\text { COEFFICIENT OF DETERMINATION } \\
\left(\mathrm{R}^{2} \text { - VALUES }\right)\end{array}$ & MODEL EQUATIONS \\
\hline \multicolumn{4}{|c|}{ Al - 2.5\% Sn IN VARIOUS CONCENTRATIONS OF HCl } \\
\hline $0.5 \mathrm{M}$ & 0.94935 & 0.90126 & $C P R=3.299919-0.618580 \operatorname{In} \tau$ \\
\hline $1.0 \mathrm{M}$ & 0.97840 & 0.95726 & $C P R=5.014043-0.885003 \operatorname{In} \tau$ \\
\hline \multicolumn{4}{|c|}{ Al-4.5\% Sn IN VARIOUS CONCENTRATIONS OF HCl } \\
\hline $0.5 \mathrm{M}$ & 0.93906 & 0.88183 & $C P R=4.910416-0.950385 \operatorname{In} \tau$ \\
\hline $1.0 \mathrm{M}$ & 0.94087 & 0.88524 & $C P R=5.275761-1.026965 \operatorname{In} \tau$ \\
\hline \multicolumn{4}{|c|}{ Al - 2.5\% Sn IN VARIOUS CONCENTRATIONS OF NaCl } \\
\hline $0.5 \mathrm{M}$ & 0.95146 & 0.90527 & $C P R=5.757208-1.028719 \operatorname{In} \tau$ \\
\hline $1.0 \mathrm{M}$ & 0.95772 & 0.91722 & $C P R=3.912334-0.713126 \operatorname{In} \tau$ \\
\hline \multicolumn{4}{|c|}{ Al-4.5\% Sn IN VARIOUS CONCENTRATIONS OF NaCl } \\
\hline $0.5 \mathrm{M}$ & 0.99582 & 0.99165 & $C P R=7.045895-1.249661 \operatorname{In} \tau$ \\
\hline $1.0 \mathrm{M}$ & 0.98574 & 0.97168 & $C P R=6.445930-1.192448 \operatorname{In} \tau$ \\
\hline
\end{tabular}

predictor of the corrosion trend in the various duplex Al-Sn alloy systems being investigated.

\section{Conclusion}

The statistical analysis of the corrosion behaviour of Al-Sn duplex alloy system has been investigated. It can be observed that the modeled values of CPR obtained from our model equations correlates well with the experimental data. This is attributed to the nearly perfect positive coefficient of correlation that obtained in the analysis which is consistent for all the alloy compositions.

\section{REFERENCES}

[1] C. E. Ekuma, "Effects of Zinc Addition on the Corrosion Susceptibility of Al-Alloys in Selected Media Concentration,” B.Sc. Project, EBSU, Nigeria, 2006.

[2] R. E. Ulick, "The Corrosion and Oxidation of Metals, 2nd Supplementary Vol. (Special Edition)," Prentice Press, New York, 1976.

[3] J. C. Zoccola, H. E. Townsed, A. R. Borzillo and J. B. Horton, "Atmosphere Corrosion Behaviour of Aluminium-Zinc Alloy Coated Steel,” STP 646, American So- ciety for Testing and Materials, Philadelphia, 1978, pp. 165-184.

[4] S. H. Zhang and S. B. Lyon, "The Electrochemistry of Iron, Zinc and Copper in Thin Layer Electrolytes," Corrosion Science, Vol. 35, No. 1-4, 1992, pp. 713-718. doi:10.1016/0010-938X(93)90207-W

[5] N. E. Idenyi, S. I. Neife and U. Uzor, “The Corrosion Behaviour of Recrystalized Mild Steel in Various Tetraoxosulphate (vi) Acid $\left[\mathrm{H}_{2} \mathrm{SO}_{4}\right]$ Concentrations," Journal of Corrosion Science and Technology, Vol. 1, No. 1, 2004, pp. 54-55.

[6] N. E. Idenyi and S. I. Neife, "The Corrosion of Aluminuim Base Alloys in Caustic Soda Media," Journal of Corrosion Science and Technology, Vol. 1, 2005, p. 10.

[7] C. E. Ekuma, N. E. Idenyi and A. E. Umahi, "The Effects of Zinc Additions on the Corrosion Susceptibility of Aluminium Alloys in Various Tetraoxosulphate (VI) Acid Environments," Information Technology Journal, Vol. 7, No. 2, 2007, pp. 237-241.

[8] C. E. Ekuma, N. E. Idenyi, F. K. Onwu and A. E. Umahi, "The Influence of Media Concentrations on the Passivation Layer Characteristics of Al-Zn Alloys in Brine Environment,” Asian Journal of Science Research, Vol. 1, No. 
2, 2007, pp. 113-121.

doi:10.3923/ajsr.2008.113.121

[9] C. E. Ekuma, N. E. Idenyi and C. D. Ossi, "The Effects of Manganese Addition on the Corrosion Susceptibility of Cast Al-Alloys in Acidic Environment," Trends in Applied Science Research, Vol. 2, No. 2, 2007, pp. 170-174.

[10] F. E. Goodwin, "Mechanism of Corrosion of Zinc and Zinc -5\% Aluminum Steel Sheet Coatings, in Zinc-Based Steel Coatings Systems: Metallurgy and Performance,” In: G. Krauss and D. K. Matlock, Eds., The Minerals Metals Materials Society, Warrendale, Pennsylvania, 1990, pp. 183-193.

[11] A. I. Onuchukwu, "The Trend of Chemical Induced Corrosion," Journal of Corrosion Science and Technology, Vol. 2, 2004, p. 138.

[12] N. E. Idenyi, C. E. Ekuma and I. O. Owate, "The Influence of Alloy Composition on the Passivation Layer Characteristics of Al-Zn Alloys Systems," Proceedings of Materials Science and Technology 2006 Meeting and Exhibition, Cincinnati, 15-19 October 2006.

[13] K. Nisancioglu, “Corrosion of Aluminium Alloys,” Proceedings of ICAA3, Trondheim, NTH and SINTEF, Vol. 3, 1992, pp. 239-259.
[14] C. E. Ekuma and N. E. Idenyi, "The Inhibition Characteristic of Brine on the Corrosion Susceptibility of Al-Zn Alloy Systems,” Journal of Applied Sciences, Vol. 6, No. 8, 2006, pp. 1751-1755. doi:10.3923/jas.2006.1751.1755

[15] N. E. Idenyi, C. E. Ekuma, J. B. Idenyi and A. E. Umahi, "The Analysis of the Effect of Manganese Addition on the Corrosion Susceptibility of Al-Mn Alloys in $\mathrm{H}_{2} \mathrm{SO}_{4}$ Environments," Proceedings of 29th Annual International Conference of Chemical Society of Nigeria (CSN), Ikeja, 25-29 September 2006.

[16] C. E. Ekuma and N. E. Idenyi, "Statistical Analysis of the Influence of Environment on Prediction of Corrosion from its Parameters," Research Journal of Physics, Vol. 1, No. 1, 2007, pp. 27-34.

[17] N. E. Idenyi, S. I. Neife and S. O. Agha, "The Effects of Tin Addition on the Corrosion Susceptibility of Al-Alloys," International Journal of Science Laboratory Tech- nology (JOSCILT), Vol. 2, No. 2, 2004, pp. 23-27. 